\title{
The Performance of Artificial Neural Network Approaches to Estimate the Nitrate Concentration in Groundwater
}

\author{
Asli Coban ${ }^{1 *}$ \\ 1*University College Dublin, School of Mechanical and Materials Science, Dublin, Ireland, (ORCID: 0000-0002-3020-0164), asli.coban@ucd.ie
}

(First received 22 January 2021 and in final form 21 November 2021)

(DOI: 10.31590 /ejosat.866497)

ATIF/REFERENCE: Coban, A. (2021). The Performance of Artificial Neural Network Approaches to Estimate the Nitrate Concentration in Groundwater. European Journal of Science and Technology, (27), 873-879.

\begin{abstract}
The estimation of the pollution concentration in groundwater is important, since it is one of the key resources of water supply. Nitrate $(\mathrm{NO} 3-\mathrm{N})$ is one of the well-known indicator parameters in groundwater pollution. Using historical data, artificial neural networks can be utilized to estimate the nitrate concentration in groundwater. In this study, a sample dataset, which is derived from a survey analysis in the literature, is used to estimate the nitrate concentration of groundwater (i.e., target parameter) with respect to six different well characteristics (i.e., input parameters). The effect of different hydrogeological parameters of the wells on the nitrate concentration is focused for the first time in this study. The performance of two different ANN approaches, namely BPNN and GRNN, is evaluated comparatively by means of their regression performances. Considering regression results of ANN models, it can be concluded that the GRNN ( $\mathrm{R}=0.99)$ algorithm works slightly better than the BPNN $(\mathrm{R}=0.98)$ algorithm with this dataset. Correlation results indicate that the most important characteristics of the wells to estimate the nitrate pollution are the well depth, depth below water table, clay above screen, and depth to well screen, respectively. Moreover, all these characteristics are inversely related to nitrate concentration of the well.
\end{abstract}

Keywords: Groundwater, Nitrate Pollution, Artificial Neural Network, Regression, BPNN, GRNN.

\section{Yapay Sinir Ağı Yaklaşımlarının Yeraltı Suyundaki Nitrat Konsantrasyonunu Tahmin Etme Performansi}

Öz

Su temininde temel kaynaklardan olduğu için yeraltı suyundaki kirlilik konsantrasyonunun tahmini önemlidir. Nitrat (NO3-N) yeraltı suyu kirliliğinde iyi bilinen gösterge parametrelerinden birisidir. Yapay sinir ağları (YSA) geçmiş veriler kullanılarak yeraltı suyundaki nitrat konsantrasyonunu tahmin etmek için kullanılabilir. Bu çalışmada, literatürdeki bir kuyu analizinden türetilen örnek bir veri seti, altı farklı kuyu özelliğine (girdi parametrelerine) göre yeraltı suyunun nitrat konsantrasyonunu (hedef parametre) tahmin etmek için kullanılmıştır. Kuyuların farklı hidrojeolojik parametrelerinin nitrat konsantrasyonu üzerindeki etkisine ilk kez bu çalışmada dikkat çekilmiştir. BPNN ve GRNN olmak üzere iki farklı YSA yaklaşımının performansı, regresyon performansları üzerinden karşılaştırmalı olarak değerlendirilmektedir. YSA modellerinin regresyon sonuçlarına bakıldığında, bu veri seti ile GRNN (R=0.99) algoritmasının BPNN ( $\mathrm{R}=0.98)$ algoritmasından biraz daha iyi çalıştığı sonucuna varılabilir. Korelasyon sonuçları, nitrat kirliliğini tahmin etmek için kuyuların en önemli özelliklerinin sırasıyla kuyu derinliği, su tablasının altındaki derinlik, elek üstü kil ve kuyu ızgarasına derinlik olduğunu göstermektedir. Ayrıca tüm bu özellikler kuyunun nitrat konsantrasyonu ile ters orantılıdır.

Anahtar Kelimeler: Yeraltı Suyu, Nitrat Kirliliği, Yapay Sinir Ağı, Regresyon, BPNN, GRNN.

\footnotetext{
* Corresponding Author: asli.coban@ucd.ie
} 


\section{Introduction}

Groundwater is the most important drinking water supply throughout the world, especially where the water resources are limited or polluted. In general, groundwater supplies roughly half of all drinking water in the world [1]. Additionally, the groundwater contributes to surface water resources through the watershed. Agricultural practices, especially excessive use of fertilizers, causes the largest diffusion threat to groundwater quality on a global scale [2-3]. Since the nitrate (NO3-N) is one of the main groundwater pollutants and can directly affect human health, it is important to evaluate the nitrate concentration in groundwater.

The natural nitrate concentration in groundwater under aerobic conditions is very low (a few milligrams per liter) and relies upon heavily on soil type and on the geological situation [4]. However, it can rise high levels through agricultural runoff, refuse dump runoff, or contamination with human or animal wastes [2]. Wells, drilled into the aquifers, enable the groundwater to be pumped out. Hence aquifer/well characteristics are other important parameters affecting the nitrate concentration in groundwater. There are different driving parameters affecting the nitrate concentration in groundwater [5]. They can be chemical or hydrogeological variables. The well depth, depth to static water table, clay above screen, well density, depth to well screen, and depth below water table (i.e., depth to groundwater) can be classified as hydrogeological variables. The depth to static water table measures the depth to groundwater level and it is being a proxy to the time that contaminants require to reach the aquifer [6]. Higher density of wells means the spatial pattern of irrigation return and more pollutant leachate into the soil and groundwater consequently [5]. Higher density areas are where potential impacts to groundwater quantity and quality will be the greatest. The potential for groundwater pollution usually increases by lower depth to groundwater [5]. It is also known that groundwater pollution in clayey formations is higher than in well-drained sandy plains [7]. Wells with long screen lengths may facilitate cross-contamination between contaminated zones [8].

Artificial neural networks (ANNs) present an informationprocessing paradigm for pattern recognition which is generally used in situations where the relationships between data are not very complex and linear [9-10]. ANNs use input-output response patterns to estimate the underlying governing rules of the output responses considering specific inputs in a convoluted physical space [9]. The aim of the training process for ANNs is to calculate the optimal weights of the links in the neural net by minimizing the overall prediction error which is known as empirical risk minimization [9]. Different machine learning models have been investigated to estimate the groundwater nitrate concentration in the literature. Table 1 represents the summary of the reviewed studies reporting the implementation of machine learning models, namely ANN and SVM, for the purpose of nitrate concentration estimation in groundwater.

Different physical, chemical, and hydrogeological parameters can be used as input variables to estimate the nitrate concentration in groundwater. Considering research remarks of the reviewed studies, it can be concluded that the applied models are robust with promising results.

In this study, a sample dataset, which is derived from a survey analysis in the literature, is used to estimate the nitrate concentration of groundwater (i.e., target parameter) with respect to six different well characteristics (i.e., input parameters). The effect of different hydrogeological parameters of the wells on the nitrate concentration is focused for the first time in this study. The performance of two different ANN approaches is evaluated comparatively by means of their regression performances. The backpropagation neural network (BPNN) and the generalized regression neural network (GRNN) were chosen as ANN approaches for this study. A multilayer perceptron (MLP) is a class of feedforward ANN which utilizes a supervised learning method for training called backpropagation (BP). A MLP neural network trained by BP algorithms, also known as the BPNN, is the most typical type of ANN which is broadly employed in environmental pollution controls [25]. GRNN as a special variation of the radial basis function neural network is being used in the field of environmental pollution controls as well [24]. Relying on nonlinear Gaussian kernel regression, a GRNN has strong nonlinear mapping ability and is able to get decent results even when the data is ambiguous [24].

Table 1. The summary of the reviewed studies reporting the implementation of machine learning models (ANN and SVM)

\begin{tabular}{l|l|l|l}
\hline Reference & Case study region & Applied models & Performance metrics \\
\hline$[11]$ & Sangamon River, USA & BPNN, RBFNN & RMSE \\
\hline$[12]$ & Harran Plain, Turkey & MLP with BP and Levenberg-Marquardt & R-value, MSE \\
\hline$[13]$ & Kutahya, Turkey & BPNN & MSE, MAPE \\
\hline$[14]$ & $\begin{array}{l}\text { Kadava River basin, Nashik, } \\
\text { Maharashtra, India }\end{array}$ & MLP with Levenberg-Marquardt & R $^{2}$, RMSE, MARE \\
\hline$[15]$ & Shandong, China & BPNN & R-value \\
\hline$[16]$ & Northern part of Iran & BPNN, RBFNN & MSE \\
\hline$[17]$ & Central Valley, California & BRT, ANN, Bayesian networks & R $^{2}$ \\
\hline$[18]$ & Bethune, France & MLP with BP & R-value \\
\hline$[19]$ & African continent & RFR, MLR & $\mathrm{R}^{2}$ \\
\hline$[20]$ & Marvdasht watershed, Iran & SVM, Cubist, random forest, Bayesian- & $\begin{array}{l}\mathrm{R}^{2}, \text { MAE, RMSE, Nash-Sutcliffe efficiency } \\
\text { (NSE) }\end{array}$ \\
\hline$[21]$ & ANN & RMSE, R-value, MAE \\
\hline$[22]$ & Gaza Strip, Palestine & MLP, RBFNN & R-value, MAPE, NSE \\
\hline$[23]$ & Gaza Strip, Palestine & Marquardt, SVM & \\
\hline$[24]$ & Arak plain, Iran & MLP, RBF, GRNN, and linear networks. & R-value \\
\hline
\end{tabular}




\section{Material and Method}

The sample well survey data used in this study is adapted from a study in the literature [26]. Table 2 represents the nitrate concentration (NO3-N, mg/L) levels of different wells with respect to different well characteristics. Although there are different supervised machine learning approaches for regression,
BPNN and GRNN are chosen for this study. Hydrogeological variables such as the well depth, depth to static water table, clay above screen, well density, depth to well screen, and depth below water table are considered potential factors influencing nitrate contamination in this study. Hence these six parameters are utilized as the input parameters whereas the NO3-N concentration is used as the target parameter.

Table 2. Sample well survey analysis

\begin{tabular}{|c|c|c|c|c|c|c|c|}
\hline Well No & $\begin{array}{c}\text { Well } \\
\text { depth }(\mathbf{m}) \\
\end{array}$ & $\begin{array}{c}\text { Depth to static } \\
\text { water table } \\
(\mathrm{m})\end{array}$ & $\begin{array}{l}\text { Clay above } \\
\text { screen }(\mathbf{m})\end{array}$ & $\begin{array}{c}\text { Well } \\
\text { density }\end{array}$ & $\begin{array}{c}\text { Depth to } \\
\text { well screen } \\
(\mathrm{m}) \\
\end{array}$ & $\begin{array}{c}\text { Depth below } \\
\text { water table }(\mathbf{m})\end{array}$ & NO3-N (mg/L) \\
\hline 1 & 10.9 & 3.9 & 0.3 & 1.0 & 7.6 & 3.6 & 11.5 \\
\hline 3 & 23.7 & 6.4 & 14.0 & 1.0 & 14.6 & 8.2 & 4.0 \\
\hline 4 & 17.3 & 5.5 & 3.9 & 1.0 & 14.3 & 8.8 & 5.2 \\
\hline 5 & 27.4 & 3.0 & 13.1 & 4.0 & 21.3 & 18.3 & 1.7 \\
\hline 8 & 8.9 & 1.8 & 4.3 & 1.0 & 58.8 & 4.0 & 3.4 \\
\hline 9 & 12.2 & 2.1 & 2.7 & 1.0 & 6.1 & 4.0 & 6.3 \\
\hline 10 & 16.7 & 3.9 & 3.6 & 3.0 & 13.7 & 9.8 & 8.1 \\
\hline 11 & 21.0 & 4.5 & 0.0 & 3.0 & 17.0 & 12.5 & 1.8 \\
\hline 12 & 19.8 & 6.1 & 9.1 & 5.0 & 13.7 & 7.6 & 8.3 \\
\hline 17 & 13.7 & 4.3 & 6.1 & 4.0 & 10.6 & 6.3 & 9.9 \\
\hline 18 & 25.6 & 6.4 & 9.1 & 1.0 & 14.6 & 8.2 & 3.6 \\
\hline 19 & 18.3 & 4.5 & 5.5 & 2.0 & 12.2 & 7.7 & 8.8 \\
\hline 20 & 18.3 & 7.9 & 11.2 & 0.0 & 15.2 & 7.3 & 5.2 \\
\hline 21 & 18.3 & 5.8 & 9.4 & 0.0 & 13.4 & 7.6 & 1.3 \\
\hline 22 & 21.0 & 5.5 & 12.5 & 1.0 & 17.9 & 12.4 & 4.0 \\
\hline 23 & 41.2 & 7.0 & 10.3 & 3.0 & 21.3 & 14.3 & 3.8 \\
\hline 24 & 28.6 & 7.6 & 20.1 & 1.0 & 22.5 & 14.9 & 5.9 \\
\hline 25 & 16.7 & 6.7 & 9.1 & 1.0 & 14.3 & 7.6 & 6.3 \\
\hline 26 & 18.3 & 7.3 & 9.1 & 2.0 & 12.2 & 4.9 & 5.9 \\
\hline 27 & 18.3 & 8.2 & 5.2 & 2.0 & 12.2 & $\begin{array}{l}4.0 \\
\end{array}$ & 3.4 \\
\hline 28 & 31.4 & 9.1 & 9.4 & 3.0 & 19.2 & 10.1 & 4.7 \\
\hline
\end{tabular}

In BPNN method, data preprocessing is performed using minimum-maximum normalization which preserves the relationship between the original data [27]. The raw data is normalized before directing to training and testing through altering the data to the range of 0 to 1 to increase the speed and accuracy of ANN performance [28]. As stated in Table 2, six input parameters and one target parameter are used to perform the BPNN algorithm using MATLAB $®$.

The number of hidden layers and output layer are used in BPNN approach are given in Fig 1. The BPNN model is trained using the Levenberg-Marquardt function. Performance of the algorithm is determined using MSE parameter and the number of epochs is chosen as 40,000 . The construction of the network (the number of neurons in hidden layers) are decided by trial and error.

As another approach GRNN is applied to the same dataset (raw data) including six input parameters and one target parameter using MATLAB $\AA$. The results of two different algorithms are compared by means of their R-values. 


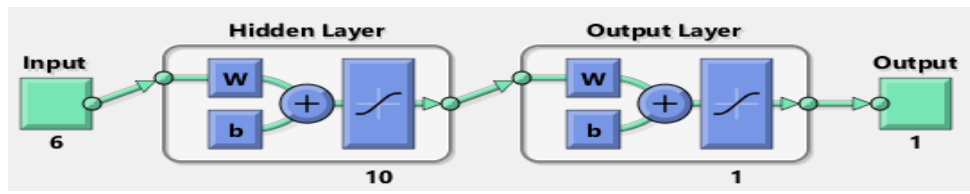

Fig 1. The architecture of the network

\section{Results and Discussion}

Linear regression analysis is performed for training, validation, and testing, to evaluate the relation among the outputs of the network and the targets. The training, validation, and test results of BPNN algorithm are given in Fig 2 with corresponding R-values.
In each plot, the dashed line describes the ideal result (i.e., outputs=targets), while the solid line presents the best fit linear regression. As the $\mathrm{R}$-value reaches to 1 , then there is an exact linear relationship. The regression results (i.e., R-values) are 0.98 , 0.98 , and 0.97 for training, validation, and test, respectively. Those results are approaching to a total response of 0.98 .
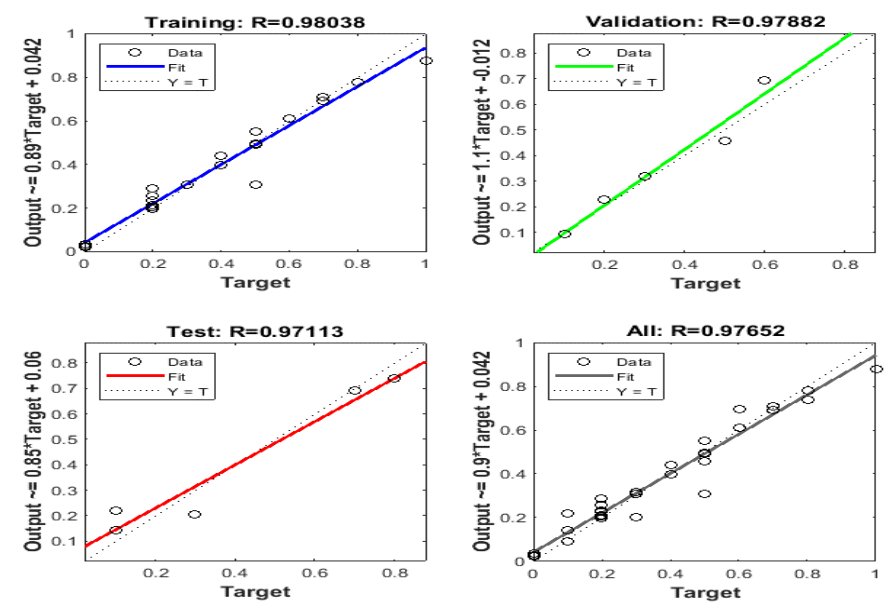

Fig 2. The training, validation, and test results of BPNN algorithm

The best validation performance of the model is given in Fig 3. In general, there is no correct value for MSE. The lower value is better and zero means the model is perfect and the predicted values are equal to measured values [29]. Considering R-values in Fig 2 and the MSE value $(\mathrm{MSE}=0.0024)$ in Fig 3, it can be concluded that the results of BPNN algorithm are promising for the estimation of nitrate concentration levels of wells if the hydrogeological parameters of the well are specified.
The result of GRNN algorithm is given in Fig 4. Considering regression results $(\mathrm{R}=0.99)$ in the Fig 4 , it can be concluded that GRNN algorithm works slightly better than BPNN algorithm with this dataset.

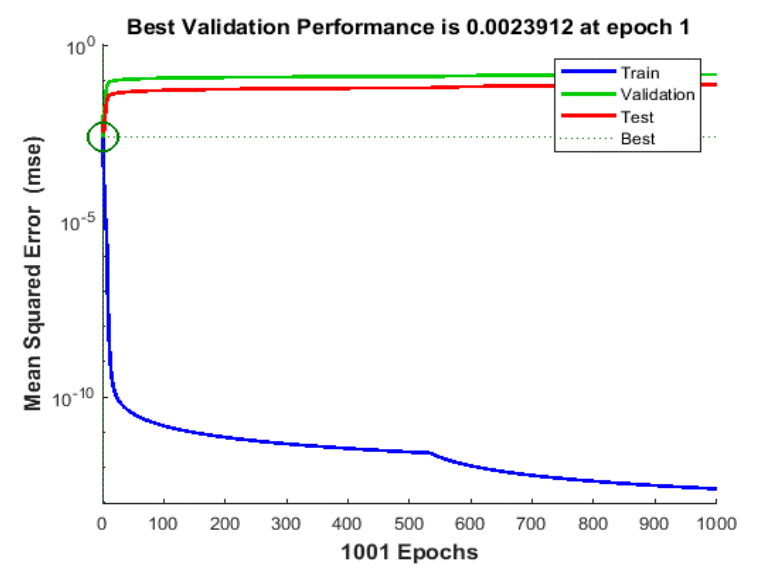

Fig 3. The best validation performance of the model 


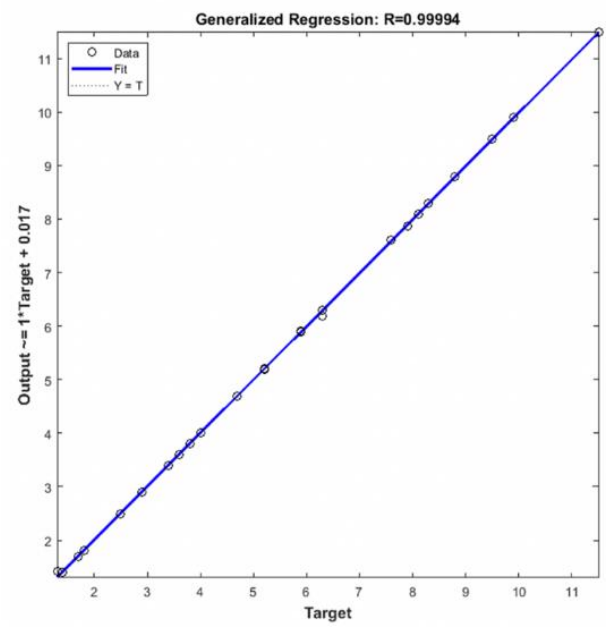

Fig 4. The result of GRNN algorithm

The R-values obtained in this study correlate with the literature values related to the nitrate concentration estimation using ANN approaches which are ranging from 0.58 to 0.99 [12$13,16,21-22,24,29,32,34]$. Similarly, the MSE values also correlate with the literature values in the range of 0.001-0.121 [12-13, 17, 19, 24, 29-31, 33].
To interpret the effect of different characteristics of the well on the nitrate concentration, the raw data (Table 2) is utilized to prepare the correlation (Fig 5) and the correlation matrix (Table $3)$.

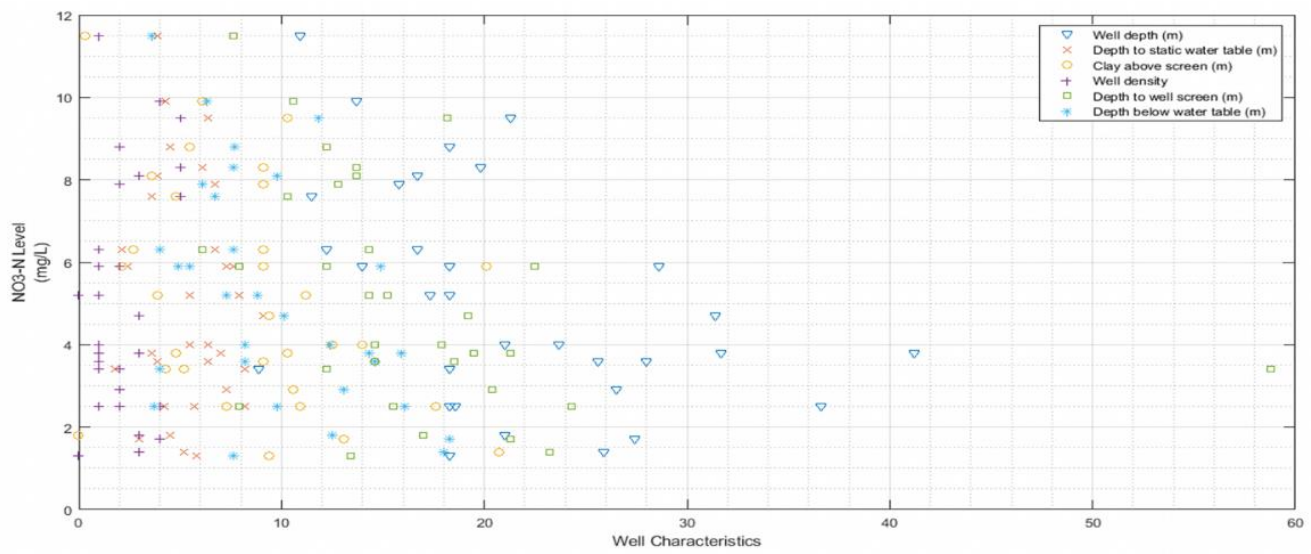

Fig 5. The correlation between well characteristics and NO3-N concentration

The correlation graph and correlation matrix are prepared using the MATLAB ${ }^{\circledR}$ and MS Office Excel software, respectively.

Considering Fig 5 and Table 3, it can be concluded that the most important characteristics of the wells to estimate nitrate pollution are the well depth, depth below water table, clay above screen, and depth to well screen respectively. Moreover, all these characteristics are inversely related to nitrate concentration of the well.

Table 3. The correlation matrix

\begin{tabular}{|c|c|c|c|c|c|c|c|}
\hline & $\begin{array}{l}\text { Well } \\
\text { Depth } \\
\text { (m) }\end{array}$ & $\begin{array}{l}\text { Depth to } \\
\text { Static Water } \\
\text { Table (m) }\end{array}$ & $\begin{array}{l}\text { Clay } \\
\text { Above } \\
\text { Screen (m) }\end{array}$ & $\begin{array}{l}\text { Well } \\
\text { Density }\end{array}$ & $\begin{array}{l}\text { Depth to } \\
\text { Well } \\
\text { Screen (m) }\end{array}$ & $\begin{array}{l}\text { Depth below } \\
\text { Water Table } \\
\text { (m) }\end{array}$ & $\begin{array}{l}\text { NO3-N } \\
(\mathrm{mg} / \mathrm{L})\end{array}$ \\
\hline Well Depth (m) & 1 & & & & & & \\
\hline Depth to Static Water Table (m) & 0.4805 & 1 & & & & & \\
\hline Clay Above Screen $(\mathrm{m})$ & 0.5931 & 0.4847 & 1 & & & & \\
\hline Well Density & 0.0358 & -0.0865 & -0.0567 & 1 & & & \\
\hline Depth to Well Screen (m) & 0.1735 & -0.0771 & 0.2409 & -0.1175 & 1 & & \\
\hline Depth below Water Table (m) & 0.7826 & 0.1511 & 0.6242 & 0.1020 & 0.2806 & 1 & \\
\hline NO3-N (mg/L) & -0.4598 & -0.1077 & -0.3749 & 0.2556 & -0.3531 & -0.4384 & 1 \\
\hline
\end{tabular}




\section{Conclusions and Recommendations}

The results of two different ANN models are promising for the estimation of nitrate concentration levels of wells if the hydrogeological parameters of the well are specified. Considering regression results of ANN models, it can be concluded that GRNN $(\mathrm{R}=0.99)$ algorithm works slightly better than $\mathrm{BPNN}(\mathrm{R}=0.98)$ algorithm with this dataset. Correlation results represent that the most important characteristics of the wells to estimate nitrate pollution are the well depth, depth below water table, clay above screen, and depth to well screen, respectively. Moreover, all these characteristics are inversely related to nitrate concentration of the well.

In conclusion, this study offers the nitrate concentration estimation based on hydrogeological parameters rather than water quality analysis parameters in contribution to the literature and confirms the applicability of ANN approaches in this area with different types of well parameters. Although a small dataset is used as a demonstration in this preliminary study, these ANN approaches can be applied to large datasets as well. The results can be improved after refining the input parameters using correlation as pre-modeling technique in addition to the normalization of the data.

\section{Acknowledge}

The author did not receive support from any organization for the submitted work and have no conflicts of interest to declare that are relevant to the content of this article.

\section{References}

[1]. WWAP (World Water Assessment Programme), (2009). Water in a Changing World. World Water Development Report 3, Paris/London, UNESCO Publishing/Earthscan.

[2]. Nas, B., \& Berktay, A. (2006). Groundwater contamination by nitrates in the city of Konya, (Turkey): A GIS perspective. Journal of Environmental Management, 79, 30-37.

[3]. Zhou, Z. (2015). A Global Assessment of Nitrate Contamination in Groundwater. Internship Report, Supervisor: N. Ansems and P. Torfs.

[4]. WHO, (2011). Background Document for Development of Guidelines for Drinking Water Quality, Nitrate and nitrite in drinking-water. WHO/SDE/WSH/07.01/16/Rev/1.

[5]. Motevalli, A., Naghibi, S.A., Hashemi, H., Berndtsson, R., Pradhan, B., \& Gholami, V. (2019). Inverse method using boosted regression tree and k-nearest neighbor to quantify effects of point and non-point source nitrate pollution in groundwater. Journal of Cleaner Production, 228, 1248-1263.

[6]. Kaddour, K., El Hacen, B., Hlima, D., \& Yasmina, D. (2018). Groundwater vulnerability assessment using GOD method in Boulimat coastal District of Bejaia area North east Algeria. Journal of Biodiversity and Environmental Sciences, 13(3), 109-116.

[7]. Pociene, A., \& Pocius, S. (2005). Relationship between nitrate amount in groundwater and natural factors. Journal of Environmental Engineering and Landscape Management, 13(1), 23-30.

[8]. Brown Jr., E.G., Rodriquez, M., \& Ingenito, M. B. (2014). Well Design and Construction for Monitoring Groundwater at Contaminated Sites. Department of Toxic Substances Control, California Environmental Protection Agency, Final.
[9]. Khalil, A., Almasri, M.N., McKee, M., \& Kaluarachchi, J. (2005). Applicability of statistical learning algorithms in groundwater quality modeling. Water Resources Research, 41 (W05010), 1-16.

[10]. Arslan, M. \& Terzioğlu, H. (2020). Estimation of Solar Radiation Value using Artificial Intelligence Networks. European Journal of Science and Technology, (Special Issue), 488-497.

[11]. Suen, J.-P., \& Eheart, J.W. (2003). Evaluation of neural networks for modeling nitrate concentrations in rivers. Journal of Water Resources Planning and Management, 129, 505-510.

[12]. Yesilnacar, M.I., Sahinkaya, E., Naz, M., \& Ozkaya, B. (2008). Neural network prediction of nitrate in groundwater of Harran Plain, Turkey. Environmental Geology, 56, 19-25.

[13]. Benzer, R., \& Benzer, S. (2018). Forecasting the Nitrate Pollution of Groundwater and Surface Waters: Kütahya Example. Karaelmas Science and Engineering Journal, 8(1), 279-287. (in Turkish)

[14]. Wagh, V., Panaskar, D., Muley, A., Mukate, S., \& Gaikwad, S. (2018). Neural network modelling for nitrate concentration in groundwater of Kadava River basin, Nashik, Maharashtra, India. Groundwater for Sustainable Development, 7, 436-445.

[15]. Huang, J., Xu, J., Liu, X., Liu, J., \& Wang, L. (2011). Spatial distribution pattern analysis of groundwater nitrate nitrogen pollution in Shandong intensive farming regions of China using neural network method. Mathematical and Computer Modelling, 54, 995-1004.

[16]. Ehteshami, M., Farahani, N. D., \& Tavassoli, S. (2016). Simulation of nitrate contamination in groundwater using artificial neural networks. Modeling Earth Systems and Environment, 2(28), 1-10.

[17]. Nolan, B.T., Fienen, M.N., \& Lorenz, D.L. (2015). A statistical learning framework for groundwater nitrate models of the Central Valley, California, USA. Journal of Hydrology, 531, 902-911.

[18]. Darwishe, H., El Khattabi, J., Chaaban, F., Louche, B., Masson, E., \& Carlier, E. (2017). Prediction and control of nitrate concentrations in groundwater by implementing a model based on GIS and artificial neural networks (ANN). Environmental Earth Sciences, 76(649), 1-14.

[19]. Ouedraogo, I., Defourny, P., \& Vanclooster, M. (2019). Application of random forest regression and comparison of its performance to multiple linear regression in modeling groundwater nitrate concentration at the African continent scale. Hydrogeology Journal, 27, 1081-1098.

[20]. Band, S.S., Janizadeh, S., Pal, S.C., Chowdhuri, I., Siabi, Z., Norouzi, A., Melesse, A.M., Shokri, M., \& Mosavi, A. (2020). Comparative Analysis of Artificial Intelligence Models for Accurate Estimation of Groundwater Nitrate Concentration. Sensors, 20(5763), 1-23.

[21]. Zaqoot, H. A., Hamada, M., \& Miqdad, S. (2018). A Comparative Study of Ann For Predicting Nitrate Concentration In Groundwater Wells In The Southern Area Of Gaza Strip. Applied Artificial Intelligence, 32(7-8), 727744.

[22]. Alagha, J.S., Said, M.A.M., \& Mogheir, Y. (2014). Modeling of nitrate concentration in groundwater using artificial intelligence approach - a case study of Gaza coastal aquifer. Environmental Monitoring and Assessment, 186, 3545. 
[23]. Al-Mahallawi, K., Mania, J., Hani, A., \& Shahrour, I. (2012). Using of neural networks for the prediction of nitrate groundwater contamination in rural and agricultural areas. Environmental Earth Sciences, 65, 917-928.

[24]. Arabgol, R., Sartaj, M., \& Ashgari, K. (2016). Predicting nitrate concentration and its spatial distribution in groundwater resources using support vector machines (SVMs) Model. Environmental Modeling and Assessment, 21, 71-82.

[25]. Ye, Z., Yang, J., Zhong, N., Tu, X., Jia, J., \& Wang, J. (2020). Tackling environmental challenges in pollution controls using artificial intelligence: A review. Science of the Total Environment, 699(134279), 1-28.

[26]. Townsend, M. A., \& Young, D.P. (1995). Factors Affecting Nitrate Concentrations in Ground Water in Stafford County, Kansas. 238, 1-9.

[27]. Jain, Y.K., \& Bhandre, S.K. (2011). Min Max Normalization Based Data Perturbation Method for Privacy Protection. International Journal of Communication and Computer Technologies, 2(8), 45-50.

[28]. Wagh, V.M., Panaskar, D.B., \& Muley, A.A. (2017). Estimation of nitrate concentration in groundwater of Kadava river basin-Nashik district, Maharashtra, India by using artificial neural network model. Modeling Earth Systems and Environment, 3(36), 1-10.

[29]. Ostad-Ali-Askari, K., Shayannejad, M., \& Ghorbanizadeh-Kharazi, H. (2017). Artificial Neural Network for Modeling Nitrate Pollution of Groundwater in Marginal Area of Zayandeh-rood River, Isfahan, Iran. KSCE Journal of Civil Engineering, 21(1), 134-140.

[30]. Foddis, M.L., Montisci, A., Trabelsi, F., \& Uras, G. (2019). An MLP-ANN-based approach for assessing nitrate contamination. Water Supply, 19.7, 1911-1917.

[31]. Mousavi, S.F., \& Amiri, M.J. (2012). Modelling Nitrate Concentration of Groundwater Using Adaptive Neural-Based Fuzzy Inference System. Soil \& Water Res., 7, 2012 (2), 7383.

[32]. Almasri, M.N., \& Kaluarachchi, J.J. (2005). Modular neural networks to predict the nitrate distribution in ground water using the on-ground nitrogen loading and recharge data. Environmental Modelling \& Software, 20, 851-871.

[33]. Kumar, P., Lai, S.H., Mohd, N.S., Kamal, M.R., Afan, H.A., Ahmed, A.N., Sherif, M., Sefelnasr, A., \& El-shafie, A. (2020). Optimised neural network model for river- nitrogen prediction utilizing a new training approach. PLoS ONE 15(9): e0239509.

[34]. Zare, A.H., Bayat, V.M., \& Daneshkare, A.P. (2011). Forecasting nitrate concentration in groundwater using artificial neural network and linear regression models. International Agrophysics, 25, 187-192. 